\title{
Penggunaan media Flash Card untuk Meningkatkan Hasil Belajar Siswa Sekolah Dasar
}

\author{
Budi Febriyanto, Ari Yanto \\ Program Studi Pendidikan Guru Sekolah Dasar, Universitas Majalengka \\ Email: budifebriyanto88@gmail.com
}

\begin{abstract}
Abstrak
Penelitian ini dilatarbelakangi oleh temuan terhadap proses pembelajaran yang berdampak terhadap hasil belajar siswa, diantaranya pembelajaran yang dilakukan masih terpusat pada guru serta penggunaan media pembelajaran kurang maksimal dan hanya terpaku pada buku pelajaran. Penelitian ini bertujuan untuk memperbaiki proses pembelajaran dengan menggunakan media flash card. Penelitian ini merupakan penelitian tindakan kelas yang dilaksanakan secara kolaboratif antara guru dan peneliti yang dilaksanakan dalam dua tindakan pada setiap siklusnya. Subjek penelitian ini adalah siswa kelas IV SDN I Pesanggrahan sebanyak 26 orang siswa. Alat pengumpulan data yang digunakan yaitu lembar tes evaluasi, lembar observasi siswa, lembar observasi guru dan foto kegiatan. Data dalam penelitian ini berupa data kuantitatif dan kualitatif yang dianalisis menggunakan analisis deskriptif kuantitatif. Hasil penelitian yang diperoleh yaitu adanya peningkatan pada hasil belajar siswa. Nilai rata-rata siswa sebelum dilakukan tindakan yaitu 52,7 dengan persentase ketuntasan siswa mencapai 30,8\%. Pada siklus I nilai rata-rata kelas yang diperoleh yaitu 66,2 dengan persentase ketuntasan siswa mencapai 53,8. Pada siklus II nilai rata-rata kelas yang diperoleh yaitu 74,7 dengan persentase ketuntasan siswa mencapai $80,8 \%$. Hasil penelitian menunjukan bahwa pelaksanaan pembelajaran dengan menggunakan media Flashcard dapat meningkatkan hasil belajar siswa pada mata pelajaran IPS di kelas IV SDN I Pesanggrahan.
\end{abstract}

Kata Kunci : hasil belajar, media flash card, pembelajaran IPS.

\section{Use of Flash Card Media to Improve Elementary Schools' Student Learning Outcomes}

\author{
Budi Febriyanto, Ari Yanto \\ Program Studi Pendidikan Guru Sekolah Dasar, Universitas Majalengka \\ Email: budifebriyanto88@gmail.com
}

This research is motivated by findings on the learning process that has an impact on student learning outcomes, including the learning that is done is still centered on the teacher and the use of instructional media is not maximal and only fixes on textbooks. This research is a classroom action research carried out collaboratively between teachers and researchers carried out in two actions in each cycle. The subjects of this study were the fourth grade students of SDN I Pesanggrahan as many as 26 students. Data collection tools used are evaluation test sheets, student observation sheets, teacher observation sheets and photos of activities. The data in this study are quantitative and qualitative data which are analyzed using quantitative descriptive analysis. The results of the research obtained were an increase in student learning outcomes. The average value of students before the action is 52.7 with the percentage of students completing reaching 30.8\%. In the first cycle the average grade value obtained was 66.2 with the percentage of student completeness reaching 53.8. In the second cycle the class average value obtained was 74.7 with the percentage of students completing reaching $80.8 \%$. The results showed that the implementation of learning using Flashcard media can improve student learning outcomes in social studies subjects in class IV SDN I Pesanggrahan..

Keywords: flash card media, learning outcomes, social studies learning. 


\section{PENDAHULUAN}

Ilmu pengetahuan sosial (IPS) merupakan salah satu mata pelajaran yang dapat memberikan wawasan pengetahuan yang sangat luas mengenai kehidupan bermasyarakat baik dalam konteks lokal maupun global sehingga IPS mampu membekali manusia untuk dapat hidup bersama-sama dengan masyarakat lainnya.

Menurut Sumaatmadja (2007: mengemukakan bahwa "Ilmu Pengetahuan Sosial (IPS) merupakan mata pelajaran atau mata kuliah yang mempelajari kehidupan sosial yang kajiannya mengitegrasikan bidang ilmu-ilmu sosial dan humaniora". Hal tersebut diperkuat oleh pendapat Supriatna (2009: 1) yang mengatakan "IPS merujuk pada kajian yang memusatkan perhatiannya pada aktivitas kehidupan manusia". Dengan demikian, dapat dikatakan bahwa IPS merupakan mata pelajaran atau bidang yang mengkaji sebuah fakta dan konsep yang berkaitan dengan isu sosial yang diadaptasi dari ilmu-ilmu sosial dan humaniora kemudian memusatkannya pada aktivitas kehidupan manusia.

Tujuan pembelajaran IPS di sekolah dasar (SD) berkaitan dengan ketercapaian tujuan ilmu-ilmu sosial yang menjadi pondasi awal peserta didik dalam mengatasi permasalahan sosial ada di lingkungannya. Tujuan kurikuler yang tercantum dalam dokumen kurikulum merupakan dasar dari tujuan pembelajaran yang dilaksanakan di kelas. Adapun tujuan tersebut mengacu pada pencapaian kompetensi dasar yang telah ditetapkan. Menurut Sardijiyo (2007: 1.28) tujuan kurikuler pendidikan IPS di SD adalah sebagai berikut. 1) Membekali peserta didik dengan pengetahuan sosial yang berguna dalam kehidupannya kelak di masyarakat. 2) Membekali peserta didik dengan kemampuan mengidentifikasi, menganalisis, dan menyusun alternatif pemecahan masalah sosial yang terjadi dalam kehidupan di masyarakat. 3) Membekali peserta didik dengan kemampuan berkomunikasi dengan sesama warga masyarakat dan berbagai bidang keilmuan serta bidang keahlian. 4) Membekali peserta didik dengan kesadaran, sikap mental yang positif dan keterampilan terhadap pemanfaatan lingkungan hidup yang menjadi bagaian dari kehidupan tersebut. 5) Membekali peserta didik dengan kemampuan mengembangkan pengetahuan dan keilmuan IPS sesuai dengan perkembangan kehidupan masyarakat, ilmu pengetahuan dan teknologi. Oleh karena itu, tujuan yang telah dikemukakan di atas menjadi acuan dalam menentukan ketercapaian ketuntasan hasil belajar siswa.

Hasil belajar dalam pembelajaran IPS tidak hanya mencakup pada salah satu ranah saja tetapi harus mencakup keseluruhan baik kognitif, afektif, dan psikomotor. Suprihatiningrum (2013: 37) menegaskan bahwa "hasil belajar adalah suatu kinerja (performance) yang diindikasikan sebagai suatu kapabilitas (kemampuan) yang telah diperoleh". Hasil belajar siswa tidak dapat diukur berdasarkan pengetahuan siswa saja 
namun harus dilihat secara keseluruhan yakni dari pengetahuan, sikap dan keterampilan yang dimiliki oleh setiap siswa akan berpengaruh terhadap hasil belajarnya. Tentunya ketercapaian hasil belajar tersebut tidak lepas dari pelaksanaan proses pembelajaran yang sedari awal sudah direncanakan oleh guru.

Berdasarkan hasil pengamatan awal terhadap proses pembelajaran IPS di kelas IV SDN 1 Pesanggrahan Kecamatan Plumbon Kabupaten Cirebon masih banyak yang mengalami kesulitan belajar sehingga siswa belum mencapai kriteria ketuntasan minimal (KKM) sebesar 70, dari 26 siswa terdapat 8 $(30,8 \%)$ siswa yang mampu mencapai nilai yang ditentukan dan sisanya 18 orang siswa memperoleh nilai di bawah KKM. Berdasarkan hasil tersebut terdapat beberapa kendala dalam proses pembelajaran sehingga berdampak terhadap hasil belajar siswa, diantaranya penggunaan media pembelajaran yang belum optimal dimanfaatkan oleh guru serta pembelajaran masih terpusat pada guru, selama proses pembelajaran keterlibatan/pastisipasi peserta didik menjadi terbatas, hal ini menyebabkan hasil belajar siswa terhadap materi pembelajaran IPS rendah serta penggunaan media pembelajaran kurang maksimal dan hanya terpaku pada buku pelajaran.

Berdasarkan temuan tersebut, sudah seharusnya dilaksanakan perbaikan terhadap proses pembelajaran salah satunya dengan menggunakan media pembelajaran. Pada proses pembelajaran media dapat membantu guru untuk menyampaikan maksud dan tujuan dari materi yang diajarkan. Menurut Sadiman dkk (2014: 7) "media adalah segala sesuatu yang dapat digunakan untuk menyalurkan pesan dari pengirim ke penerima pesan sehingga dapat merangsang pikiran, perasaan, perhatian dan minat siswa sedemikian rupa sehingga proses belajar terjadi”. Ada beberapa jenis media yang dapat digunakan salah satunya media Flash card.

Media flash card merupakan media sederhana yang dapat dipergunakan oleh guru dalam menyampaikan isi materi pada pembelajaran IPS. Menurut Asyhar (2012:4) "Jika dilihat dari bentuknya flash card termasuk media grafis atau media dua dimensi, yaitu media yang mempunyai ukuran panjang dan lebar dan secara khusus untuk mengkomunikasikan pesan-pesan pendidikan, media ini dapat digunakan untuk mengungkapkan fakta melalui penggunaan kata-kata, angka serta bentuk simbol atau lambang". Lebih lanjut dikemukakan oleh Susilana dan Riyana (2008: 91) bahwa "Flashcard memiliki kelebihan diantaranya: (a) mudah dibawa-bawa; (b) praktis; (c) gampang diingat; dan (d) menyenangkan. Lebih lanjut dikemukakan oleh Fitriyani dan Nulanda (2017: 172) bahwa "flash cards merupakan media yang sangat praktis karena dapat dibuat secara bersama-sama oleh guru dan siswa. Salah satu indikasi bahwa visual imagery memiliki kemungkinan memberikan kode memori yang efektif adalah siswa 
biasanya lebih mudah dalam mengenali gambar daripada tulisan”. Dengan demikian penggunaan media flash card dapat dijadikan solusi dalam mengatasi permasalah proses pembelajaran yang telah dipaparkan dengan harapan dapat membantu siswa meningkatkan hasil belajarnya.

\section{METODE}

Penelitian ini adalah penelitian tindakan kelas. Setiap siklus terdiri dari empat tahapan yaitu planning (perencanaan), acting (pelaksanaan), observing (pengamatan), dan reflecting (refleksi) tahapan tersebut dapat digambarkan menggunakan desain penelitian berdasarkan desain penelitian model John Elliot. Berikut desain penelitian yang akan digunakan:

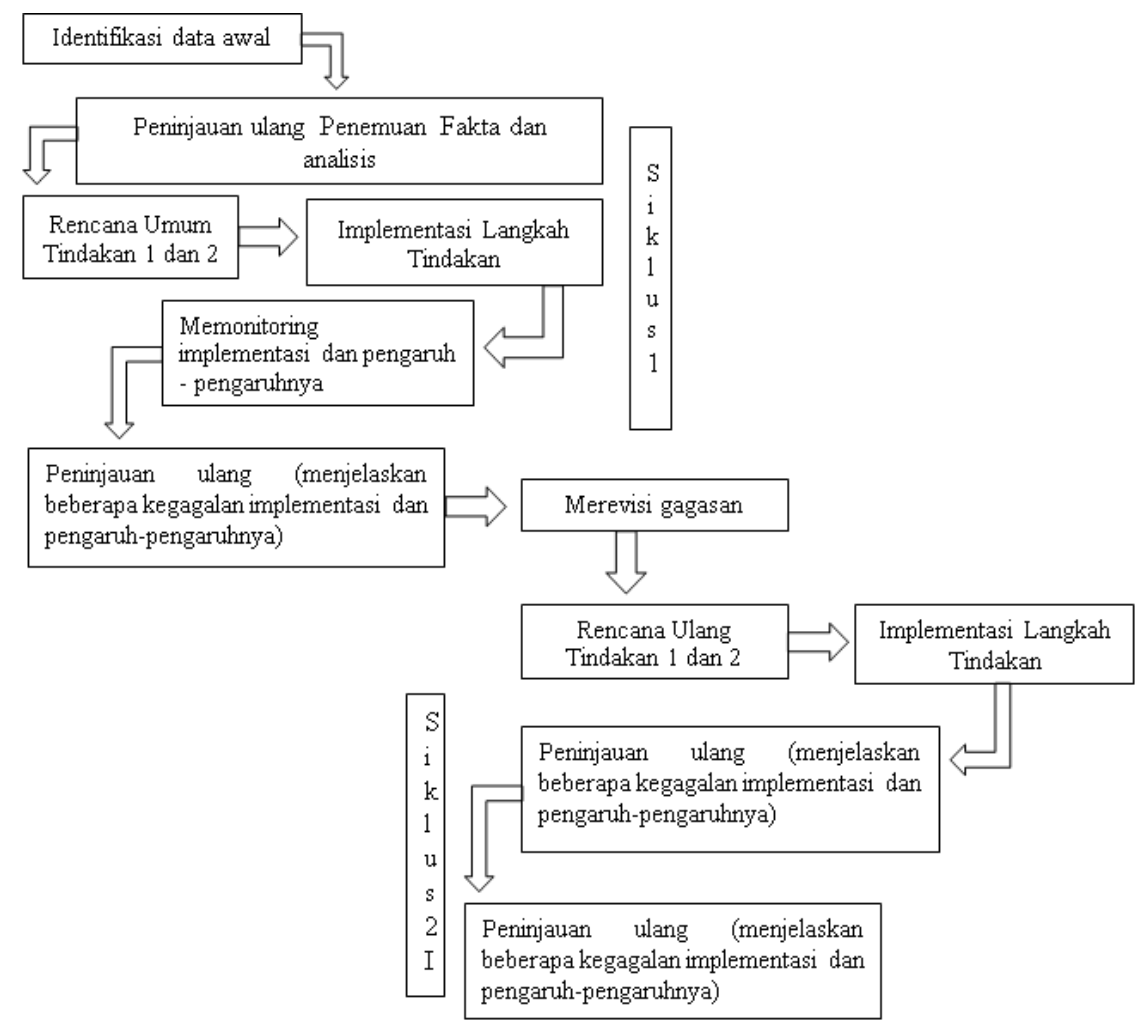

Gambar 1. Adaptasi Alur PTK Model John Elliot (Wiriaatmadja, 2013: 64)

Pada tahap identifikasi data awal, peneliti memperoleh data awal berdasarkan pertemuan dengan pihak sekolah berdasarkan temuan yang ada. Selanjutnya pada tahap peninjauan ulang, penemuan fakta dan analisis peneliti pratindakan untuk menemukan fakta dan menganalisisnya.
Pada pelaksanaan siklus I peneliti melaksanakan empat tahapan yaitu: Rencana Umum Tindakan 1 dan 2. Peneliti merencanakan pelaksanaan kegiatan yang akan dilaksanakan yaitu waktu pelaksanaan serta menentukan observer kemudian menyusun RPP, Lembar Observasi Siswa dan Lembar Observasi Guru. Selanjurnya pada 
implementasi langkah tindakan, peneliti melaksanakan proses kegiatan pembelajaran sesuai dengan rencana pelaksanaan pembelajaran yang telah dibuat sebelumnya. Tahap berikutnya adalah memonitoring Implentasi dan pengaruh-pengaruhnya, peneliti melibatkan observer untuk membantu mengobservasi siswa dan guru. Peninjauan ulang atau biasa disebut Refleksi, merupakan tahapan dimana peneliti dan observer melakukan analisis data yang diperoleh selama melaksanakan tindakan. Kemudian menyusun perencanaan untuk siklus berikutnya. Kegiatan dilakukan secara bersiklus sampai ketuntasan belajar mencapai target yang telah ditentukan.

Subjek penelitian ini adalah siswa kelas IV SDN I Pesanggrahan Kecamatan Plumbon Kabupaten Cirebon. Jumlah keseluruhan siswa adalah 26 siswa yang terdiri dari 15 siswa laki-laki dan 11 siswa perempuan. Instrumen yang digunakan dalam penelitian ini diantaranya lembar observasi guru dan siswa, lembar wawancara, dokumentasi, dan tes. Teknik analisis data yang digunakan dalam penelitian adalah yang digunakan dalam penelitian adalah Tindakan 2 analisis deskriptif kuantitatif untuk Rata-rata menganalisis hasil tes evaluasi siswa setiap siklus dan analisis deskriptif kualitatif untuk menganalisis hasil observasi, wawancara, dan catatan lapangan setiap siklus. Data hasil penelitian ini divalidasi dengan validasi bentuk triangulasi. peneliti memilih jenis validasi data menggunakan triangulasi karena data yang diperoleh dalam penelitian ini merupakan data yang diperoleh secara serentak yaitu data hasil observasi siswa dan guru, data hasil evaluasi dan data dokumentasi.

\section{HASIL DAN PEMBAHASAN}

Hasil observasi selama proses pembelajaran terhadap aktivitas guru mengalami peningkatan pada setiap tindakan untuk setiap siklusnya. Pada siklus I tindakan 1 proses pembelajaran masih kaku dan belum maksimal namun pada tindakan 2 terjadi peningkatan namun belum signifikan dan pada siklus I dapat disimpulkan bahwa hasil observasi terhadap aktivitas guru mendapat kriteria C (Cukup) dengan prosentase 74,7\% maka aktivitas guru masih perlu perbaikan. Pada siklus II terjadi peningkatan yang cukup signifikan aktivitas guru mendapat kriteria B (Baik) dengan persentase mencapai 92,4\% dan telah mencapai kriteria yang diharapkan. Berikut peningkatan yang terjadi pada aktivitas guru disajikan dalam bentuk tabel:

Tabel 1. Rekapitulasi Persentase Observasi Aktivitas Guru

\begin{tabular}{ccc} 
Tindakan & Siklus I & Siklus II \\
\hline Tindakan 1 & $72,2 \%$ & $90,7 \%$ \\
Tindakan 2 & $77,2 \%$ & $94,1 \%$ \\
\hline Rata-rata & $74,7 \%$ & $92,41 \%$ \\
\hline Kriteria & C (Cukup) & A (Baik Sekali) \\
\hline
\end{tabular}

Berdasarkan data hasil observasi aktivitas guru dapat dilihat bahwa pada setiap tindakan yang dilakukan selalu terjadi peningkatan. Pada tindakan 1 siklus I mendapatkan persentase sebesar $72,2 \%$ dan meningkat sebesar $6,92 \%$ menjadi $77,2 \%$ pada tindakan 2 siklus I kemudian pada siklus 
II mendapatkan persentase sebesar 90,7\% atau meningkat sebesar $17,5 \%$ dan pada tindakan 2 Siklus II mendapatkan persentase sebesar $94,1 \%$ atau meningkat sebesar $3,7 \%$. Jika dilihat dari rata-rata presentse persiklusnya bahwa persentase siklus I sebesar $74,7 \%$ dan meningkat sebesar $17,7 \%$ yaitu menjadi 92,41\% pada siklus II. Kriteria yang diperoleh berdasarkan hasil observasi terhadap aktivitas guru yaitu A (Sangat Baik). Dengan hasil terserbut dapat dikatakan bahwa penelitian ini menunjukan adanya peningkatan terhadap proses pembelajaran pada aktivitas guru dalam pembelajaran IPS di kelas IV SDN 1 Pesanggrahan Kecamatan Plumbon Kabupaten Cirebon.

Proses pembelajaran tidak lepas dari peran guru dan siswa didalamnya maka selain menggunakan lembar observasi aktivitas guru penelitian ini juga menggunakan lembar observasi kegiatan siswa sebagai instrumen untuk melihat peningkatan terhadap proses pembelajaran. Hasil pengamatan terhadap siswa dalam proses pembelajaran disajikan dalam tabel sebagai berikut:

Tabel 2. Rekapitulasi Persentase Observasi Aktivitas Siswa

\begin{tabular}{ccc}
\hline Tindakan & Siklus I & Siklus II \\
\hline Tindakan I & $64,1 \%$ & $82,2 \%$ \\
Tindakan 2 & $72,2 \%$ & $86,6 \%$ \\
\hline Rata - Rata & $68,2 \%$ & $84,4 \%$ \\
\hline Kriteria & C (Cukup) & B (Baik) \\
\hline
\end{tabular}

Berdasarkan tabel di atas terlihat bahwa terjadi peningkatan terhadap aktivitas siswa secara bertahap pada siklus I tindakan 1 diperoleh hasil sebesar $64,1 \%$ dan meningkat pada tindakan 2 sebesar $12,6 \%$ yaitu menjadi $72,2 \%$ dan rata rata hasil observasi terhadap pada siklus I sebesar $68,2 \%$ dengan hasil tersebut aktivitas siswa belum dikatakan memperoleh hasil yang diinginkan maka perlu dilakukan siklus II. Pada siklus II diperoleh hasil sebesar $82,2 \%$ pada tindakan 1 dan meningkat sebesar $5,4 \%$ menajadi $86,6 \%$ dan rata-rata aktivitas siswa pada siklus II sebesar $84,4 \%$. Hasil observasi pada siklus II dapat disimpulkan bahwa telah terjadi peningkatan dari siklus sebelumnya sebesar $23,7 \%$ dan dengan rata-rata hasil aktivitas siswa mendapatkan kriteria $\mathrm{B}$ (baik) maka penelitian ini dikatakan selesai karena telah mencapai kriteria yang diinginkan.

Hasil penelitian tersebut sejalan dengan yang disampaikan dalam penelitian Maghfiroh (2013: 10) bahwa "keseluruhan hasil penelitian menunjukkan adanya peningkatan, baik aktivitas guru, aktivitas siswa maupun hasil siswa dalam kegiatan pembelajaran tematik. Aktivitas dan peran guru yaitu guru tidak lagi menjadi sumber satu-satunya dalam kegiatan pembelajaran tematik tetapi guru menjadi fasilitator dan pembimbing. Aktivitas siswa yang dimaksud adalah peran siswa yang aktif saat proses pembelajaran tematik". Dengan demikian, dapat disimpulkan bahwa media flash card memberikan kontribusi positif dalam meningkatkan aktivitas dalam proses pembelajaran baik dari segi aktivitas guru dan 
aktivitas siswa. Berdasarkan hasil penelitian terhadap proses pembelajaran IPS dengan menggunakan media flashcard di kelas IV SDN Plumbon selama melaksanakan tindakan pada dua siklus diperoleh hasil yang positif yaitu terjadinya peningkatan pada setiap siklusnya baik pada lembar aktivitas guru dan siswa maupun pada hasil belajar berupa tes yang dilakukan setelah proses pembelajaran.

Hasil belajar siswa pada pra siklus perolehan nilai belum memuaskan dari 26 siswa nilai tertinggi yaitu 80 dan nilai terendah 35 dengan rata-rata nilai 52,7 hasil yang diperoleh belum memuaskan karena dapat diindikasikan bahwa hasil belajar siswa sangat rendah terlihat dari hasil rata-rata nilai yang diperoleh belum mencapai nilai KKM sebesar 70 dengan persentase kelulusan sebesar 30,8\% sedangkan persentase ketuntasan yang sebesar $80 \%$, maka dari hasil tersebut dilakukan penelitian tindakan kelas.

Penelitian ini dilaksanakan dalam dua siklus dan setiap siklusnya terdiri dari dua tindakan. Hasil dari penelitian yang dilaksanakan pada siklus I belum begitu memuaskan namun ada peningkatan hasil belajar dari pra siklus, hasil belajar tersebut yaitu dari 26 siswa nilai tertinggi yaitu sebesar 85 dan nilai terendah 50 dengan rata-rata nilai hasil belajar sebesar 66,2 dari hasil rata-rata nilai yang diperoleh belum mencapai nilai KKM dengan ketuntasan siswa pada siklus I sebesar 53,8\% atau 14 dari 26 orang siswa yang mampu mencapai nilai KKM, hasil tersebut mengindikasikan bahwa penelitian ini belum mencapai hasil yang diinginkan dan perlu dilaksanakan siklus selanjutnya.

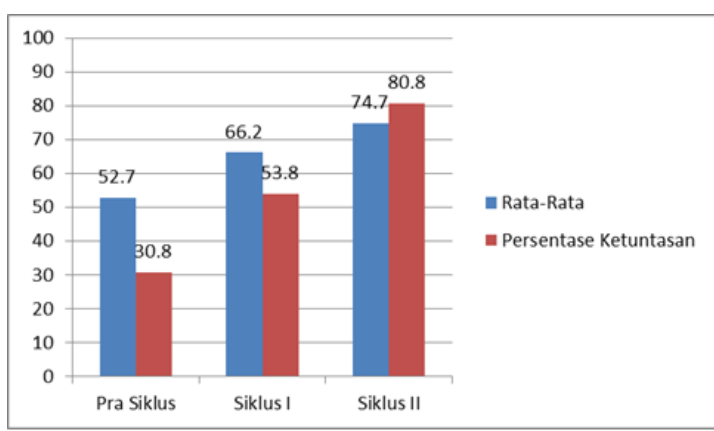

Gambar 2. Grafik Rekapitulasi Hasil Belajar Siswa

Hasil dari siklus II setelah melakukan perbaikan terhadap temuan pada siklus I hasil belajar siswa yang diperoleh mengalami peningkatan dengan nilai terbesar 95 dan nilai terendah 55 dengan rata-rata nilai sebesar 74,7 dari hasil rata-rata nilai yang diperoleh telah mencapai nilai diatas KKM dengan ketuntasan sebesar 80,8\% atau 21 dari 26 orang siswa yang mampu mencapai nilai KKM. Perolehan hasil belajar pada siklus II telah mencapai kriteria yang diinginkan maka penelitian ini diangap selesai. Peningkatan hasil belajar yang telah diperoleh dapat disajikan pada gambar sebagaimana berikut ini:

Salah satu tujuan penelitian ini adalah untuk meningkatkan hasil belajar siswa, menurut Slameto (2003:7) "hasil belajar adalah sesuatu yang diperoleh dari suatu proses usaha setelah melakukan kegiatan belajar yang dapat diukur dengan menggunakan tes guna melihat kemajuan siswa" kemudian ditegaskan oleh Suprihatiningrum (2013: 37) bahwa "hasil 
belajar adalah suatu kinerja (performance) yang diindikasikan sebagai suatu kapabilitas (kemampuan) yang telah diperoleh". Hasil belajar tidak lepas dari aktifitas belajar siswa secara menyeluruh maka dapat dikatakan bahwa hasil belajar akan diperoleh setelah siswa selesai melaksanakan proses pembelajaran di kelas. Dalam dunia pendidikan menurut Bloom secara garis besar membagi hasil belajar menjadi tiga ranah, yakni 'ranah kognitif, ranah afektif, dan ranah psikomotor' (Sudjana, 2009 : 22). Seorang guru dalam proses pembelajaran harus mempunyai kriteria yang dapat meningkatkan hasil belajar siswa, dalam proses penelitian ini peneliti berupaya meningkatkan hasil belajar siswa secara menyeluruh artinya berupaya meningkatkan hasil belajar siswa. Berdasarkan data tersebut maka penelitian ini dapat meningkatkan hasil belajar siswa di kelas IV SDN Plumbon dengan menggunakan media flashcard. Keberhasilan media flash card dalam memberikan pengaruh terhadap hasil belajar juga dikemukakan oleh Natalia dan Susarno (2015: 6) bahwa bahwa “ yang menyebabkan post-test dari kelompok eksperimen meningkat adalah perlakuan media pembelajaran flashcard materi alat musik tradisional Indonesia sehingga dari analisis tersebut dapat disimpulkan bahwa pemanfaatan media pembelajaran flashcard alat musik tradisional Indonesia dapat meningkatkan hasil belajar pada mata pelajaran IPS materi alat musik tradisional siswa kelas V SDN Balongsari 7 Mojokerto".
Berdasarkan hal tersebut, maka dalam penelitian ini media flash card mampu memberikan efek positif dengan meningkatnya hasil belajar siswa pada siklus I dan siklus II serta memenuhi kriteria ketuntasan klasikal pada pokok bahasan kegiatan ekonomi memanfaatkan sumber daya alam.

\section{KESIMPULAN DAN SARAN}

Berdasarkan pembahasan yang telah dipaparkan, diperoleh simpulan bahwa proses pembelajaran dengan menggunakan media flasd card pada mata pelajaran IPS di kelas IV SDN I Pesanggrahan berdasarkan hasil observasi yang dilakukan memperoleh hasil yang memuaskan. Hal tersebut berdasarkan hasil observasi terhadap aktivitas guru dan observasi terhadap siswa pada proses pembelajaran. Hasil belajar siswa kelas IV pada mata pelajaran IPS dengan menggunakan media flash card pada mata pelajaran IPS di SDN I Pesanggrahan berdasarkan tes dan observasi/pengamatan terhadap siswa memperoleh hasil yang positif.

Hasil penelitian ini sangat diharapkan dapat memotivasi terhadap perbaikan proses pembelajaran karena dengan menggunakan media flash card siswa menjadi lebih aktif dan mudah untuk diajak berinteraksi, dengan adanya hal tersebut memudahkan guru dalam penyampaian materi serta siswa memahami materi yang diajarkan sehingga dapat meningkatkan hasil belajar siswa. Penggunaan media flash card diharapkan dapat dikembangkan lebih lanjut dalam proses 
pembelajaran di kelas terhadap mata pelajaran dan materi yg lainnya, selain itu penelitian ini agar dapat digunakan sebagai studi pustaka yang bermanfaat.

\section{DAFTAR PUSTAKA}

Asyhar, R. (2012). Kreatif Mengembangkan Media Pembelajaran. Jakarta: Referensi Jakarta.

Fitriyani, E. dan Nulanda, P.Z. Efektivitas Media Flash Cards Dalam Meningkatkan Kosakata Bahasa Inggris. Psympathic: Jurnal Ilmiah Psikologi. 4, (2), hlm.167-182.

Maghfiroh, L. (2013). Penggunaan Media Flashcard untuk Meningkatkan Hasil Belajar Ips Pada Pembelajaran Tematik di Sekolah Dasar. Jurnal Penelitian Pendidikan Guru Sekolah Dasar. 1, (2), hlm. 1-13.

Natalia, M.D. dan Susarno, L.H. (2015). Pemanfaatan Media Pembelajaran Flashcard untuk Meningkatkan Hasil Belajar Mata Pelajaran IPS Materi Alat Musik Tradisonal Indonesia pada Siswa Kelas V SDN Balongsari 7 Mojokerto. Jurnal Mahasiswa Teknologi Pendidikan. 6, (2), hlm. 1-7.

Sadiman, A.S, dkk. (2014). Media Pendidikan Pengertian, Pengembangan, dan Pemanfaatannya. Jakarta: PT Raja Grafindo Persada.
Sardjiyo, dkk. (2007). Pendidikan IPS di SD. Jakarta : Universitas Terbuka.

Slameto. (2003). Belajar dan Faktor-faktor yang Mempengaruhinya. Jakarta: Rineka Cipta.

Sudjana N. (2009). Penilaian Hasil Proses Belajar Mengajar. Bandung: PT. Remaja Rosdikarya.

Sumaatmadja, N. (2007). Materi Pokok Konsep Dasar IPS. Jakarta : Universitas Terbuka.

Supriatna, N., dkk. (2009). Bahan Belajar Mandiri Pendidikan IPS di SD. Bandung: UPI Press.

Suprihatiningrum, J. (2013). Strategi pembelajaran Teori dan Aplikasi. Yogyakarta: AR-RUZZ Media.

Susilana R. dan Riyana C. (2008). Media Pembelajaran. Bandung: CV Wacana Prima.

Wiriaatmaja, R. (2013). Metode Penelitian Tindakan Kelas. Bandung: PT. Remaja Rodakarya. 